\title{
ORGANIC AGRICULTURE: THE TRADE-OFF BETWEEN FINANCIAL AND NON-FINANCIAL BENEFITS
}

\author{
Joset-Jordaan Marais* \\ University of Johannesburg \\ josetjordaan@gmail.com \\ Received: February 2015
}

\author{
Riëtte Eiselen" \\ University of Johannesburg
}

Accepted: September 2015

\begin{abstract}
The threats of climate change have compelled humans to consider the environmental impact of their decisions, including those relating to agricultural practices. Organic agriculture is believed to be a mitigating factor when it comes to climate change. This paper explores the perceptions of organic farmers regarding the benefits of organic agriculture, from a financial and non-financial perspective. It also highlights the trade-off between the perceived non-financial and financial benefits of organic agriculture. A convenience sample of 26 farmers was obtained. The utility of a convenience sample was necessary due to the unavailability of a complete database of organic farms in South Africa. Results indicated that the perceived non-financial benefits of organic agriculture were considered to be the most important consideration for the decision to farm organically. The results confirmed and augmented those found by other authors, namely that the environmental benefits of organic agriculture were considered to be very important to organic farmers.
\end{abstract}

Keywords

Organic agriculture, organic farming, South Africa, financial benefits, non-financial benefits

*Ms J Jordaan-Marais is a lecturer in the Department of Finance and Investment Management, University of Johannesburg, South Africa.

\#Prof $\mathbf{R}$ Eiselen is an associate professor in the Department of Finance and Investment Management, University of Johannesburg, South Africa. 


\section{INTRODUCTION}

The threats of climate change have become too serious to ignore. It has thus become necessary for humans to consider the environmental impact of their decisions, including those relating to agricultural practices. Organic agriculture is considered to be a mechanism to mitigate climate change: it reduces greenhouse gases, because no chemical nitrogen fertilisers are used; it stores carbon in soil and plant biomass by building organic matter; it encourages agro-forestry and inhibits the clearance of primary ecosystems; and it minimises energy consumption by eliminating the energy required to manufacture synthetic fertilisers and by using internal farm inputs (IFOAM, 2007).

Organic agriculture is not only a mitigating factor in terms of climate change but has the additional benefit of contributing to human health (IFOAM, 2006). It is widely accepted that good nutrition is vital for maintaining health and preventing disease (Lundegardh \& Martensson, 2003). According to Lundegardh and Martensson (2003), there is an increased consumer demand for food that is produced organically. The reasons for the increased demand for organically produced foods are their assumed high nutritional quality and quantity, and their high amounts of beneficial minerals, essential amino acids and vitamins (IFOAM, 2006). In addition, organically produced foods have no or low residues of harmful chemicals, resulting in reduced consumption of potentially harmful pesticides, because pests are managed ecologically by organic farmers (IFOAM, 2006).

Based on the above arguments it is evident that organic agriculture holds not only significant environmental benefits but also health benefits for humans. Even though several studies have included the identification of the benefits of organic agriculture in the past, most of them did not focus on the financial benefits of organic agriculture or on whether non-financial benefits are viewed as more important than financial benefits to the farmer. In addition, very few studies conducted in the past have focused on South African organic agriculture.

This paper aims to identify the perceived benefits that organic agriculture has to offer from the farmer's perspective, as well as to determine whether the non-financial benefits outweigh the financial benefits when the decision to farm organically is made. All of this will be addressed within the South African context.

\section{BACKGROUND}

The research questions addressed in this study focussed on the benefits of using organic agriculture or converting from conventional to organic agriculture, as well as the trade-off between the perceived non-financial and financial benefits of organic agriculture from the farmer's perspective. Various studies have shown that organic agriculture holds benefits of both a financial and non-financial nature. These benefits, identified in prior research, can be categorised as environmental, social and financial benefits.

\subsection{Environmental benefits}

According to Lotter (2003), the environmental cost of organic agriculture is substantially lower than that of conventional agriculture. The environmental benefits of organic agriculture include the mitigation of climate change; preservation and improvement of soil fertility; increased levels 
of carbon sink; minimised water use; and the preservation and enhancement of biodiversity (Cobb et al., 1999; Williamson, Ferrigno \& Vodouhe, 2005; Gomiero, Paoletti \& Pimentel, 2008).

In terms of the mitigation of climate change the options include: improved crop and grazing land management, and restoration of soil and degraded land (Smith et al., 2007). Soil carbon sequestration is responsible for most of the mitigation potential (Smith et al., 2007) and also plays a role in reducing erosion and minimising the impact on native ecosystems (LaSalle \& Hepperly, 2008).

As far as increased biodiversity is concerned, organic farms generally have a higher biodiversity and increased soil health, and are more energy-efficient than conventional farms (Stokstad, 2002; Lotter, 2003; Nierenberg, 2005). Furthermore, organic agriculture eliminates the need to use chemical fertilisers and pesticides, which reduces the nutrient and chemical pollution in waterways, resulting in cleaner waterways over the long term (LaSalle \& Hepperly, 2008).

\subsection{Social benefits}

Organic agriculture also holds social benefits (Cobb et al., 1999; Gomiero et al., 2008), as it reduces health problems, maintains food security (Williamson et al., 2005) and provides job opportunities (Pearson, 2007). In terms of the promotion of human health, organic food is believed to play an important role due to its high nutritional quality and quantity, and reduction of harmful chemicals (Lotter, 2003; IFOAM, 2006; Gomiero et al., 2008). In addition, raising livestock organically promotes livestock health and reduces the risk of cattle contracting or carrying diseases (IFOAM, 2006).

As far as the creation of job opportunities is concerned, organic agriculture holds another social benefit because it is, in general, labour-intensive, due to its lower dependency on mechanical procedures (Nierenberg, 2005). As a consequence, it can contribute to the upliftment of surrounding communities by offering additional job opportunities, rural and social capital and community livelihood (Pearson, 2007). The latter is of direct benefit to South Africa, as the country's unemployment rate was calculated as being $24.3 \%$ at the end of September 2014 (Statistics South Africa, 2015).

\subsection{Financial benefits}

Although Nierenberg (2005) argued that organic agriculture is associated with lower yields, various other studies have shown that it is as profitable as conventional agriculture, if not more so (Cobb et al., 1999; Sean, Klonsky, Livingston and Temple, 1999; Padel, 2001; Pimentel, Hepperly, Hanson, Douds \& Seidel, 2005; Williamson et al., 2005; Olgun, Adanacioglu \& Saner, 2006; Philpott, Bichier, Rice \& Greenberg, 2007). Furthermore, Mendoza (2004) noted that the financial benefits of organic agriculture are the following: cash expenses are lower, net revenue is higher (despite slightly lower yields) and the breakeven point is lower.

The author (ibid.) expanded on his argument that organic agriculture has lower expenses, explaining that it requires no herbicide and molluscide spraying; organic soil needs less preparation time; weed growth is decreased; and total labour cost is lower, as the high cost of labour to spray pesticides is no longer required. In contrast, some authors found organic agriculture's labour cost to be higher than that of conventional agriculture (Lotter, 2003).

Lotter (2003) argued that gross profit margins for organic agriculture are similar or higher than those of conventional agriculture. These are attributed to a reduction in input costs such as those 
associated with pesticides, synthetic fertilisers and fossil fuel energy per unit-of-yield as well as favourable price premiums (Lotter, 2003; Nierenberg, 2005; Pearson, 2007). Organic farmers, in general, get a premium price for organic products mainly due to lower yields compared with conventional agriculture (Pimentel et al., 2005; Olgun et al., 2006; Pearson, 2007; Källander \& Rundgren, 2008). Because organic products contribute to human health and the environment, and are of high quality, consumers are also prepared to pay a higher price for these products because they believe that it is value for money (Pearson \& Henryks, 2008).

Even though studies have shown that organic agriculture can be more profitable than conventional agriculture, most farmers initially experience a negative financial impact while in the conversion process. O'Riordan and Cobb (2001) found that profitability declined as the proportion of farm land in conversion increased. The decline is attributed to the fact that products produced on land still in conversion could not be sold as organic and thus not at a premium price. This situation changed once the farm achieved organic status.

The study by 0'Riordan and Cobb (2001) showed that organic production generated a higher gross margin than non-organic production after reaching organic status. Production is more expensive during the in-conversion phase. After this transition period, similar yields are experienced to those previously produced under conventional methods (Pimentel et al., 2005; Williamson et al., 2005), but production takes place at a lower cost per hectare (Horrigan, Lawrence \& Walker, 2002).

Organic agriculture compares favourably with conventional agriculture when the comparison includes a full cost accounting of the environmental and health harms and benefits of each (Horrigan et al., 2002). For example, if a conventional system produces a higher yield than a sustainable system but also degrades local water supplies due to pesticide runoff, the benefits of the higher yield may be offset by the environmental clean-up cost (Horrigan et al., 2002). When the full cost arising from the cultivation and raising of twelve food commodities, grown in the UK, were compared to organic agriculture, organic agriculture consistently showed a lower cost (Pretty, Ball, Lang \& Morison, 2005).

Previous studies have also aimed to identify the motivational factors for conversion to organic agriculture in an effort to explain the benefits of organic agriculture.

\subsection{Motivational factors for conversion}

The factors which motivate farmers to convert to organic agriculture are both financial and nonfinancial in nature (Padel, 2001). Some studies have shown that strong environmentally orientated values were the main motivation for the adoption of organic agriculture and that these were stronger motivations than economics (Lotter, 2003). Other studies have indicated that even though social, environmental and economic incentives motivated farmers to use organic methods, economic reasons were often most important (Blank \& Thompson, 2004). Several studies have been conducted to determine the common motives for conversion. These motivational factors are summarised in TABLE 1 . 
Jordaan-Marais \& Eiselen

TABLE 1: Factors motivating conversion

\begin{tabular}{|c|c|}
\hline Factors & Author(s) \\
\hline \multicolumn{2}{|l|}{ Environmental factors } \\
\hline Erosion problems & Padel (2001) \\
\hline \multicolumn{2}{|l|}{ Conservation } \\
\hline Nutrients are recycled through composting & Crucefix (1998) \\
\hline Avoiding soil loss & Crucefix (1998) \\
\hline Locally produced pest control treatments are used & Crucefix (1998) \\
\hline \multirow[t]{3}{*}{ Environmental reasons } & $\begin{array}{l}\text { Dubgaard and Sorensen in Fairweather } \\
\text { (1999) }\end{array}$ \\
\hline & $\begin{array}{l}\text { Milder, Negrave and Schoney in } \\
\text { Fairweather(1999) }\end{array}$ \\
\hline & Padel (2001) \\
\hline Concerns regarding environmental degradation & Svenson in Fairweather (1999) \\
\hline Detrimental effects of synthetic chemicals & $\begin{array}{l}\text { Conacher and Conacher in Fairweather } \\
\text { (1999) }\end{array}$ \\
\hline \multirow[t]{2}{*}{ Soil fertility } & Padel (2001) \\
\hline & $\begin{array}{l}\text { Conacher and Conacher in Fairweather } \\
\text { (1999) }\end{array}$ \\
\hline Pollution of water and soils & $\begin{array}{l}\text { Conacher and Conacher in Fairweather } \\
\text { (1999) }\end{array}$ \\
\hline Environmental and healthy alternative & Fisher in Fairweather (1999) \\
\hline $\begin{array}{l}\text { Concerns about farming practices regarding soil } \\
\text { degradation }\end{array}$ & Rigby, Young and Burton (2001) \\
\hline Concerns regarding the use of chemicals & Fairweather, (1999) \\
\hline Concerns for the soil & Fairweather, (1999) \\
\hline Environment-orientated values & Lotter (2003) \\
\hline Increasingly stringent pesticide regulations & Guthman in Lotter (2003) \\
\hline \multicolumn{2}{|l|}{ Social factors: Health } \\
\hline Animal health concerns & Padel (2001) \\
\hline $\begin{array}{l}\text { Personal health concerns: } \\
\text { Own and family health problems } \\
\text { Heath risk from applying chemicals }\end{array}$ & Padel (2001) \\
\hline \multirow[t]{2}{*}{ Food quality } & Padel (2001) \\
\hline & Svenson in Fairweather (1999) \\
\hline Health concerns & Williamson, Ferrigno and Vodouhe (2005) \\
\hline
\end{tabular}




\begin{tabular}{|c|c|}
\hline Factors & Author(s) \\
\hline & $\begin{array}{l}\text { Lockeretz and Madden in Fairweather } \\
\text { (1999) }\end{array}$ \\
\hline & Rigby, Young and Burton (2001) \\
\hline & Fairweather (1999) \\
\hline Healthy food & $\begin{array}{l}\text { Milder, Negrave and Schoney in } \\
\text { Fairweather(1999) }\end{array}$ \\
\hline Avoiding the dangers of using pesticides & Hong in Fairweather (1999) \\
\hline Environmental and healthy alternative & Fisher in Fairweather (1999) \\
\hline Concerns regarding chemicals in food & Fairweather, (1999) \\
\hline \multicolumn{2}{|l|}{ Other social factors } \\
\hline Rural development & Padel (2001) \\
\hline \multicolumn{2}{|l|}{ Financial factors } \\
\hline \multicolumn{2}{|l|}{$\begin{array}{l}\text { Securing long-term survival } \\
\text { Cost saving }\end{array}$} \\
\hline $\begin{array}{l}\text { Economic arguments dominate farmers' choices and } \\
\text { practices }\end{array}$ & Schoon and Te Grotenhuis (2000) \\
\hline Limited funds to purchase fertilisers & $\begin{array}{l}\text { Harris, Lloyd, Hofny-Collins, Barrett and } \\
\text { Browne (1998) }\end{array}$ \\
\hline Local on-farm-based techniques are used & Crucefix (1998) \\
\hline Stable revenue & Williamson, Ferrigno and Vodouhe (2005) \\
\hline Farm profitability & Svenson in Fairweather (1999) \\
\hline Economic incentives & $\begin{array}{l}\text { Bruckmeier, Grund, Symes and Jansen in } \\
\text { Fairweather (1999) }\end{array}$ \\
\hline Cost of fuel, fertilisers and biocides & $\begin{array}{l}\text { Conacher and Conacher in Fairweather } \\
\text { (1999) }\end{array}$ \\
\hline Higher profitability due to low input & Fisher in Fairweather (1999) \\
\hline \multirow[t]{2}{*}{ Financial concerns } & Fisher in Fairweather (1999) \\
\hline & Rigby, Young and Burton (2001) \\
\hline \multirow[t]{3}{*}{ Price premiums } & Padel (2001) \\
\hline & Fairweather, (1999) \\
\hline & Guthman in Lotter (2003) \\
\hline \multicolumn{2}{|l|}{ Philosophical and personal factors } \\
\hline Stewardship & Padel (2001) \\
\hline
\end{tabular}




\begin{tabular}{|c|c|}
\hline Factors & Author(s) \\
\hline $\begin{array}{l}\text { Strong convictions about the relation between man and } \\
\text { nature }\end{array}$ & Padel (2001) \\
\hline Lack of transparency in conventional system & Williamson, Ferrigno and Vodouhe (2005) \\
\hline Personal satisfaction & Fisher in Fairweather (1999) \\
\hline $\begin{array}{l}\text { Lifestyle choices: ideological, philosophical or } \\
\text { religious }\end{array}$ & $\begin{array}{l}\text { Rigby, Young and Burton (2001) Willer } \\
\text { and Gillmor in Fairweather (1999) }\end{array}$ \\
\hline Organic philosophy & Fairweather, (1999) \\
\hline Professional challenge & Padel (2001) \\
\hline
\end{tabular}

Sources: Several as indicated in table

The factors which motivate farmers to convert to organic agriculture are mainly environmental, health and financial factors, as can be seen from TABLE 1 . Farmers perceive organic methods to have a positive effect on the soil, increasing its fertility and avoiding its degradation. Many farmers who have opted to convert to organic agriculture have a strong concern for the environment and the effect that the use of synthetic fertilisers and pesticides have on the environment. They are also concerned about the effect of these pesticides on their personal health and the health of their family, workers and livestock. Some have indicated that they were motivated by financial considerations, as organic agriculture could increase farm profitability because it is a low input system, resulting in cost savings, and the fact that organic products can be sold at a premium.

Even though several studies have included the identification of the benefits of organic agriculture in the past, most of them have not determined whether non-financial benefits are viewed as more important than financial benefits. In addition, very few studies conducted in the past have focused on South African organic agriculture. This paper aims to identify, from a South African perspective, the perceived benefits that organic agriculture has to offer as well as to determine whether the non-financial benefits outweigh the financial benefits.

\section{METHODOLOGY}

Due to the fact that there is a paucity of information on the financial aspects of organic agriculture in South Africa, an exploratory study was conducted. A web-based survey was conducted, by way of a questionnaire posted on a website, to collect both quantitative data, using closed-ended questions, and qualitative data, using open-ended questions. Respondents were invited by email to access the website and fill in the online questionnaire. Confidentiality of the information supplied was assured and respondents had the option to remain anonymous.

The data yielded by the closed-ended questions was analysed by obtaining frequency distributions of each question, while content analysis was used to analyse the open questions in order to identify similarities, differences and anomalies in responses.

The scope of the study was limited to South African farms predominantly involved in horticultural activities such as fruit, vegetables, berries and herbs, all of which can be classified as perishable foods. The target population in this study was farmers who: 
- $\quad$ are in the process of converting to organic agriculture (Scenario 1);

- have fully converted to organic agriculture (Scenario 2);

- have been under organic management since inception (Scenario 3); or

- are using a combination of conventional and organic methods (Scenario 4).

These scenarios represent the different types of involvement of farmers in organic agriculture and the respondent groups mentioned in the findings of the study. The scenarios were created by the researcher and were incorporated in the questionnaire when it was developed.

Non-probability sampling using a convenience sampling technique was employed, as it was not possible to construct a complete sampling frame, i.e. a complete list of farms using organic methods. An email invitation, which included an introduction to the study, a request to participate in the study and the link to the online questionnaire were sent to the respondents. Contact information of the respondents was obtained from a South African organic agriculture website's database.

\subsection{Description of the sample}

Approximately 100 farmers were contacted of which 44 responded to the questionnaire. Only 26 of these respondents completed the questionnaire in full. The respondents came from seven of the nine provinces, with the majority, namely $39 \%$, from the Western Cape. $73 \%$ of the respondents were male, and $27 \%$ were female. The current owners became the title holders of their farms between 1906 and 2010. The respondents, who were either farm managers or the owners themselves, took control of farming activities between 1984 and 2011. The current scale of farming operations was classified as either small (69\%) or medium (31\%). Some $42 \%$ of the respondents are currently using 10 hectares or less for farming activities. $31 \%$ are using between 20 to 35 hectares and $27 \%$ are using more than 100 hectares. $77 \%$ of the respondents indicated that they produced horticultural produce only. 0 thers produced additional products such as meat and dairy.

\subsection{Research instrument}

The questionnaire used in the study was developed by the researcher, but included questions adapted from a published questionnaire used in a previous study by Niemeyer (2002). It comprised two main sections:

- The first section was completed by all respondents and was aimed at obtaining background information about the respondents;

- The second section comprised sub-sections. Each sub-section contained unique questions aimed at a specific type of farmer, i.e. a specific scenario, as mentioned above. Each respondent completed only the sub-section relevant to his/her current situation. Although the sub-sections contained questions adapted to the particular respondent's scenario, the questions were still similar in nature and addressed the same themes. The questions applicable to this paper addressed the respondent's:

- view of organic agriculture;

- perceptions regarding organic agriculture's benefits;

- savings due to using organic methods;

- current profitability and to what it could be attributed; 
- motivational factors to use organic methods.

\section{FINDINGS}

This paper aimed to identify the perceived benefits that organic agriculture has to offer from the farmer's perspective, as well as to determine whether the non-financial benefits outweigh the financial benefits when the decision to farm organically is made. Specific questions were included in the questionnaire to identify these perceived financial and non-financial benefits and their importance to the farmer.

\subsection{The perceived benefits of using organic methods}

All respondents were asked to list the benefits that they have received from using organic methods, in order of importance. This was an open-ended question. Answers were classified and grouped by the researcher using prior research as guide.

The answers to this question indicated that the respondents considered the most important benefits of organic agriculture to be (in order of importance): social benefits, especially in terms of health, since no chemicals, poisons or artificial fertilisers are used; environmental benefits, since it enhances soil fertility; financial and marketing benefits due to, among other things, the lower costs associated with pesticides and artificial fertilisers, an increasing market for organic products, and higher market prices.

The respondents thus viewed the perceived non-financial benefits of organic agriculture as more important than the perceived financial benefits.

The perceived non-financial benefits, namely environmental and social benefits, listed by the respondents, are in accordance with those mentioned by other authors (Cobb et al., 1999; Williamson et al., 2005; Gomiero et al., 2008). Environmental benefits included the mitigation of climate change, preserving and improving soil fertility, increasing the carbon sink, minimising water use, and preserving and enhancing biodiversity. Social benefits such as the improvement of both human and animal health are also in accordance with the research of authors such as Crucefix (1998), Williamson et al. (2005), and Urena, Bernabeu and Olmeda (2008). Pimentel et al. (2005) and Gomiero et al. (2008) concluded that organic agriculture improves health, as it prohibits the use of harmful chemicals. These benefits were also expressed by the respondents namely, that organic agriculture does not use chemicals, poisons or artificial fertilisers.

The financial benefits listed by the respondents included that organic agriculture results in: lower production cost, as no poisons are required and farms produce their own compost; higher sales; higher prices received for organic products; improved income; and stable or increased production. The marketing benefits listed included: access to niche markets; access to overseas markets; growing demand for organic products; and increased credibility. These sentiments were also expressed by authors such as Lotter (2003), Mendoza (2004) and Pearson (2007) - namely, that organic agriculture had lower input cost; Nierenberg (2005), who attributed the financial benefits to the elimination of the cost of pesticides and synthetic fertilisers; and Pimental et al. (2005), Olgun et al. (2006) Pearson (2007) and Källander and Rundgren (2008), who attributed the financial benefits of organic production to higher income due to the favourable price premiums of organic products. 


\subsection{Motivational factors to convert to or use organic methods}

All respondents were asked to use a scale to identify how important certain motivational factors were when deciding to use organic methods:

1 Not considered / Not applicable

2 Not important

3 Moderately important

4 Very important

TABLE 2 illustrates how respondents rated the importance of environmental, social and financial motivational factors in terms of the scale provided.

TABLE 2: Motivational factors to convert to or use organic agriculture

\begin{tabular}{|c|c|c|c|c|}
\hline Factors & $\begin{array}{l}\text { Very to } \\
\text { moderately } \\
\text { important }\end{array}$ & Not important & $\begin{array}{c}\text { Not } \\
\text { considered/ } \\
\text { Not applicable }\end{array}$ & Non-response \\
\hline \multicolumn{5}{|l|}{ ENVIRONMENTAL } \\
\hline Protecting the environment & 20 & & & 6 \\
\hline Improvement of soil fertility & 20 & & & 6 \\
\hline \multicolumn{5}{|l|}{ SOCIAL: Health } \\
\hline $\begin{array}{l}\text { Improvement of livestock } \\
\text { health }\end{array}$ & 12 & 2 & 6 & 6 \\
\hline $\begin{array}{l}\text { Increasing nutritional value of } \\
\text { product }\end{array}$ & 18 & 1 & 1 & 6 \\
\hline \multicolumn{5}{|l|}{ SOCIAL: Other } \\
\hline New challenge & 19 & & 1 & 6 \\
\hline Philosophical/spiritual reasons & 13 & 2 & 3 & 8 \\
\hline $\begin{array}{l}\text { Reduction of dependency on } \\
\text { inputs from outside industry }\end{array}$ & 16 & 2 & 1 & 7 \\
\hline \multicolumn{5}{|l|}{ FINANCIAL } \\
\hline $\begin{array}{l}\text { Higher prices for organic } \\
\text { products }\end{array}$ & 9 & 7 & 4 & 6 \\
\hline $\begin{array}{l}\text { Low profitability of } \\
\text { conventional enterprises }\end{array}$ & 10 & 3 & 5 & 8 \\
\hline $\begin{array}{l}\text { High cost of commercial } \\
\text { pesticides }\end{array}$ & 8 & 5 & 7 & 6 \\
\hline High cost of fuel & 6 & 7 & 6 & 7 \\
\hline Reduction in input cost & 13 & 2 & 4 & 7 \\
\hline Better export opportunities & 12 & 5 & 2 & 7 \\
\hline
\end{tabular}

Source: Analysis of survey 
Motivational factors of an environmental nature were seen as most important to respondents. Lotter (2003) also indicated that strong environmental values were a stronger motivational factor for the adoption of organic agriculture than economic motivations.

Social factors were the second most important motivation for converting to or using organic methods, while financial factors were the third most important. This finding is in contrast with other studies that indicated that even though social, environmental and economic incentives motivated farmers to use organic methods, financial reasons were often most important (Blank and Thompson, 2004).

\subsection{Profitability while using organic methods}

All respondents were asked to describe the profitability of their farm by choosing one of the following options: very profitable; profitable; breaking even; making a loss; making a large loss. Respondents were then asked to identify to what they attributed this profitability, if applicable. This was an open-ended question.

In terms of the profitability of organic farming operations, there were varied responses. Of the respondents who answered the question $5 \%$ classified their farm as very profitable; $30 \%$ as profitable; $30 \%$ as breaking even; and $35 \%$ as making a loss.

It can thus be argued that the majority of farmers considered profitability, or rather the lack thereof (making a loss or breaking even), as a disadvantage of organic agriculture. Whether this situation will remain the same in future is debatable, especially if the market for organic products increases. This statement can be justified by the fact that high selling prices in comparison to the input cost of organic agriculture was identified as the most important factor to which the profitability could be attributed. Other reasons for the profitability of organic agriculture included marketing opportunities becoming available due to the fact that quality products are produced organically.

The issue of profitability is in line with the theory that using organic agriculture initially leads to losses, while the farm is still in conversion, but that it translates into profits later (0'Riordan \& Cobb, 2001): The majority of farmers who were still in the conversion stage reported a loss; the respondent who was fully converted was breaking even; the majority of farmers who took control of fully converted farms either reported a profit or were breaking even; while those who used a combination of organic and conventional methods tended either to report a loss or were breaking even.

\section{CONCLUSION}

The research objective of this paper was to identify the perceived benefits that organic agriculture has to offer from the farmer's perspective, as well as to determine whether the non-financial benefits outweigh the financial benefits when the decision to farm organically is made.

Although the respondents taking part in the study agreed that organic agriculture had nonfinancial benefits, they had mixed views in terms of its financial benefits. Many financial issues, especially the high cost of labour, high certification fees and additional capital outlay, were considered as clear financial disadvantages. However, savings on fertiliser, chemicals and pesticides, potentially higher selling prices for products as well as advantages in terms of marketing were viewed as benefits or potential financial benefits. 
The study examined the trade-off between the non-financial and financial benefits of organic agriculture and found that the perceived non-financial benefits outweighed the perceived financial benefits. Most of the benefits listed were of a social nature, with a focus on health benefits and the elimination of chemicals, poisons and artificial fertilisers. Of interest is that the benefit of an increase in job opportunities was not mentioned as a social benefit by any of the respondents.

Environmental benefits, including increased biodiversity and enhanced soil fertility, were seen as the second most important benefit. The financial benefits of using organic agriculture, including the marketing benefits, were only ranked third.

A number of motivational factors were found to be important when the decision to use organic methods was made. These were: improvement of soil fertility; protecting the environment; increasing the nutritional value of the product; reduction of the dependency on inputs from outside industry; improvement of livestock health; and the challenge posed by these new methods. Clearly, none of these motivational factors were of a financial nature. In terms of financial incentives, reduction in input cost and better export opportunities were seen as relatively important.

This study adds to the existing body of knowledge by highlighting the trade-off between the perceived non-financial and financial benefits of organic agriculture. It also highlights the challenges experienced by organic farmers and those in the process of conversion. The results confirmed and augmented those found by other authors, namely that the environmental benefits of organic agriculture were considered to be very important to organic farmers (Cobb et al., 1999; Williamson et al., 2005; Gomiero et al., 2008).

The results from the study supply information to those farmers who are considering using organic methods. Although the study showed that there are both financial benefits as well as disadvantages, organic agriculture has clear environmental and social benefits. Although the environmental and social benefits may be immediate, the financial benefits tend to be realised over the long term.

\subsection{Limitations}

The study was of limited scope, due to the lack of a complete sampling frame of farmers engaged in organic farming operations. In addition, the focus was only on farms involved in the production of perishable foods. In terms of completed questionnaires, the respondents were mostly situated in one province, namely the Western Cape, and mainly classified the scale of the farming activities as small. The latter may have influenced their answers to some of the questions contained in the questionnaire. Due to these limitations, the results of the survey cannot be generalised to other types of organic farming activities. They do, however, provide an indication of the sentiments regarding motivational factors, and the benefits of using organic methods.

\subsection{Recommendations for further research}

The study could be extended to include farmers producing perishable foods not currently using organic methods as well as to organic farmers who are not producing perishable foods. It is furthermore suggested that the current study be repeated in future in order to gauge how perceptions have changed as the market for organic products expands. The issue of the necessity 
of a guide to change from conventional to organic farming may also be explored as well as the issue of creating a clear policy on certification for organic farmers.

\section{LIST OF REFERENCES}

Blank, S.C. \& Thompson, G.D. (2004). Can/Should/Will a niche become the norm? Organic agriculture's short past and long future. Contemporary Economic Policy, 22(4), pp. 483-503.

Cobb, D., Feber, R., Hopkins, A., Stockdale, L., O’Riordan, T., Clements, B., Firbank, L., Goulding, K., Jarvis, S. \& Macdonald, D. (1999). Integrating the environmental and economic consequences of converting to organic agriculture: evidence from a case study. Land Use Policy 16, pp. 207-221.

Crucefix, D. (1998). Organic Agriculture and Sustainable Rural Livelihoods in Developing Countries. A study commissioned by the Natural Resources and Ethical Trade Programme managed by Natural Resources Institute and conducted by the Soil Association in the context of the Department for International Development Natural Resources Advisors Conference in July 1998.

Fairweather, J.R. (1999). Understanding how farmers choose between organic and conventional production: Results from New Zealand and policy implications. Agriculture and Human Values, 16, pp. 51-63.

Gomiero, T., Paoletti, M.G. \& Pimentel, D. (2008). Energy and environmental issues in organic and conventional agriculture, Critical Reviews in Plant Sciences, 27(4), pp. 239-254.

Harris, P.J.C., Lloyd, H.D., Hofny-Collins, A.H., Barrett, A.R. \& Browne, A.W. (1998). Organic agriculture in sub-Saharan Africa: farmer demand and potential for development. Henry Doubleday Research Association, UK.

Horrigan, L., Lawrence, R.S. \& Walker, P. (2002). How sustainable agriculture can address the environmental and human health harms of industrial agriculture. Environmental Health Perspectives, $110(5)$, pp. $445-456$.

IFOAM (2006). Organic agriculture and human health. Available from: http://www.IF0AM.org. (Accessed 28 August 2008).

IFOAM (2007). Organic agriculture's role in countering climate change. Available from: http://www.IFOAM.org. (Accessed 28 August 2008).

Källander, I. \& Rundgren, G. (2008). Building sustainable organic sectors. Report prepared for IFOAM 2008.

LaSalle, T. \& Hepperly, P. (2008). Regenerative organic farming: A solution to global warming. Report prepared for Rodale Institute 2008.

Lotter, D.W. (2003). Organic agriculture. Sustainable Agriculture, 21(4), pp. 59-128.

Lundegardh, B. \& Martensson, A. (2003). Organically produced plant foods - Evidence of health benefits. Soil and Plant Science, 53, pp. 3-15.

Mendoza, T.C. (2004). Evaluating the benefits of organic farming in rice agroecosystems in the Philippines. Journal of Sustainable Agriculture, 24(2), pp. 93-115.

Niemeyer, K. (2002). An analysis of the conversion to organic farming in South Africa with special focus on the Western Cape. University of Stellenbosch, Unpublished Master of Science dissertation.

Nierenberg, D. (2005). Organic agriculture boosts biodiversity, World Watch, 18(1), p. 22. 
Olgun, A., Adanacioglu, H. \& Saner, G. (2006). An economic evaluation on organic cherry production: a case of Turkey. Journal of Sustainable Agriculture, 28(2), pp. 117-130.

O'Riordan, T. \& Cobb, D. (2001). Assessing the Consequences of Converting to Organic Agriculture. Journal of Agricultural Economics, 52(1), pp. 22-35.

Padel, S. (2001). Conversion to organic farming: A typical example of the diffusion of an innovation? Sociologia Ruralis, 41 (1), pp. 40-61.

Pearson, C.J. (2007). Regenerative, semi closed systems: A priority for twenty-first-century agriculture. Bioscience, 57(5), pp. 409-418.

Pearson, D. \& Henryks, J. (2008). Marketing organic products: Exploring some of the pervasive issues, Journal of Food Products Marketing, 14(4), pp. 95-108.

Philpott, S.M, Bichier, P., Rice, R. \& Greenberg, R. (2007). Field-Testing Ecological and Economic Benefits of Coffee Certification Programs. Conservation Biology, 21(4), pp. 975-985.

Pimentel, D., Hepperly, P., Hanson, J., Douds, D. \& Seidel, R. (2005). Environmental, Energetic, and Economic Comparisons of Organic and Conventional Farming Systems. BioScience, 55(7), pp. 573582.

Pretty, J.N., Ball, A.S., Lang, T. \& Morison, J.I.L. (2005). Farm costs and food miles: An assessment of the full cost of the UK weekly food basket. Science direct, Food policy, 30, pp. 1-19.

Rigby, D., Young, T. \& Burton, M. (2001). The development of and prospects for organic farming in the United Kingdom. Food Policy, 26(1), pp. 599-613.

Schoon, B. \& Te Grotenhuis, R. (2000). Values of farmers, sustainability and agricultural policy. Journal of Agricultural and Environmental Ethics, 12, pp. 17-27.

Sean, C., Klonsky, K., Livingston, P. \& Temple, S.T. (1999). Crop yield and economic comparisons of organic low input and conventional farming systems in California's Sacramento Valley. American Journal of Alternative Agriculture, 14(3), pp. 109-121.

Smith, P., Martino, D., Cai, Z., Gwary, D., Janzen, H., Kumar, P., McCarl B., Ogle, S., O’Mara, F., Rice, C., Scholes, B. \& Sirotenko, 0. (2007). Agriculture. In Climate Change 2007: Mitigation. Contribution of Working Group III to the Fourth Assessment Report of the Intergovernmental Panel on Climate Change [B. Metz, O.R. Davidson, P.R. Bosch, R. Dave \& L.A. Meyer (eds.)], Cambridge University Press, Cambridge, United Kingdom and New York, NY, USA.

Statistics South Africa (2015). Available from: http://beta2.statssa.gov.za/?page_id=737\&id=1. (Accessed 11 February 2015)

Stokstad, ع. (2002). Organic farms reap many benefits, Science, 296(5573), p. 1589.

Urena, F., Bernabeu, R. \& Olmeda, M. (2008). Women, men and organic food: differences in their attitudes and willingness to pay. A Spanish case study. International Journal of Consumer Studies, 32, pp. 18-26.

Williamson, S., Ferrigno, S. \& Vodouhe, S.D. (2005). Needs-based decision-making for cotton problems in Africa: A response to Hillocks. International Journal of Pest Management, 51(4), pp. 219224. 